\title{
FATE OF AN ABSORBENT GELLING MATERIAL FOR HYGIENE PAPER PRODUCTS IN LANDFILL AND COMPOSTING
}

\author{
R. Stegmann*, S. Lotter*, L. King $\dagger$ and W. D. Hopping $\ddagger$ \\ * Arbeitsbereich Abfallwirtschaft und Stadttechnik, Technische Universität Hamburg-Harburg. \\ Postfach 901052-2100 Hamburg, Germany, †The Procter \& Gamble Company, Cincinnati, Ohio, \\ U.S.A. and $\ddagger$ Procter \& Gamble GmbH, Schwalbach, Germany
}

(Received 28 January 1992, accepted 15 September 1992)

\begin{abstract}
A cross-linked polyacrylate polymer, referred to as absorbent gelling material (AGM), has been developed for use in hygiene paper products, such as infant diapers (nappies). The fate and effects of this polymer were studied in laboratory models of landfill and aerobic composting. Radiolabelled $\left({ }^{14} \mathrm{C}\right) \mathrm{AGM}$ was used to facilitate determination of fate and mass balance. Tests were conducted in 1201 reactors containing a mixture of solid waste and compost or solid waste only, and panty diaper pads. Controlled temperature and leachate recycle were used to accelerate the biological processes. AGM caused no adverse effects and most of the material remained associated with the diaper pad and surrounding waste. Very little AGM (less than $1 \%$ ) biodegraded to $\mathrm{CO}_{2} / \mathrm{CH}_{4}$ under landfill conditions, while $2-4 \%$ appeared in leachate. The leachate was highly biodegradable aerobically. More of the AGM $(6.4 \%)$ biodegraded to $\mathrm{CO}_{2}$ under aerobic composting conditions, while less than $1 \%$ appeared in leachate.
\end{abstract}

Key Words-Pant diapers (liners), nappies, absorbent gelling material (AGM), polyacrylate, landfill simulation, composting simulation, test reactors, ${ }^{14} \mathrm{C}$-analysis.

\section{Introduction}

\section{I Background}

Used panty diapers (liners) in domestic waste in Germany account for about $2.8 \%$ by weight on average. This figure includes the body soil; the diaper itself contributes about $1 \%$ by weight. These figures are also generally true for other western European countries.

Recently, new forms of panty diapers have been developed which are thinner and have a significantly reduced dry weight. This is achieved by the addition of a lightly crosslinked, high molecular weight polyacrylate polymer, referred to as absorbent gelling material (AGM). Up to 136,000 tonnes of these polymers are used annually in the U.S. for diapers and other absorbent products (Martin et al. 1987a, b) and approximately 70,000 tonnes are used in Western Europe.

A major part of municipal solid waste (MSW) in Germany is disposed to landfill $(69 \%)$; about $28 \%$ is incinerated and $3 \%$ composted. The situation is similar for Western Europe more broadly, with about $60 \%$ of MSW being landfilled and $34 \%$ incinerated (Carra \& Cossu 1990). Some countries incinerate a significant fraction of their MSW, e.g. Denmark, France, Sweden and Switzerland. The fraction composted is low in all 
countries, but composting of organic solid waste is expected to grow significantly as part of integrated waste management.

\subsection{Basic biological processes in sanitary landfill and composting}

In the surface area of a landfill, as well as in solid waste that is recently deposited, aerobic degradation processes take place to a certain degree. Since the contact time of the waste with air is relatively short, it is expected that only easily degradable components biodegrade. The processes are comparable to those that take place in an aerobic composting plant. The intensity of the degradation processes is lower than in composting plants, however, since optimum conditions (e.g. water content, temperature, nutrients) are not present. Under aerobic conditions, bacteria decompose organic fractions of the waste mainly to $\mathrm{CO}_{2}$ and $\mathrm{H}_{2} \mathrm{O}$; in addition, heat is produced. The organic fractions of the waste that are biologically degraded are mainly paper and cardboard $(c$. $25-30 \%$ of MSW) as well as vegetative waste (c. $30-40 \%$ of MSW).

The main degradation processes for organic solid waste in landfills take place under anaerobic conditions. In this case, the organic degradable fractions are predominately converted to $\mathrm{CH}_{4}$ and $\mathrm{CO}_{2}$. Waste components are decomposed by bacterial exoenzymes into amino acids, glucose and so on. These components are further degraded into organic acids and alcohols. Other kinds of bacteria are able to produce $\mathrm{H}_{2}, \mathrm{CO}_{2}$ and acetic acid from the hydrolysis products. Completely different kinds of bacteria (methanogens) convert these compounds into $\mathrm{CO}_{2}$ and $\mathrm{CH}_{4}$ with a comparatively low energy surplus.

It is important for the understanding of landfill processes to keep in mind that the acid-producing bacteria have much faster multiplication rates than methane-producing bacteria (by a factor of about 10-20). That means that only organic acids are produced in the initial phase of biochemical degradation processes. The methane production starts after a considerable amount of time. If the concentrations of organic acids are too high the $\mathrm{pH}$ will fall and methane production can be inhibited. In the methane phase, anaerobic biodegradation of the organic acids formed in the acid phase takes place, yielding $\mathrm{CH}_{4}$ and $\mathrm{CO}_{2}$, and the $\mathrm{pH}$ rises. The system is not inhibited if there is a balance of methane and acid-producing bacteria (Christensen \& Kjeldsen 1989, Stegmann \& Spendlin 1989).

\subsection{Objectives}

The potential release of AGM from landfilled diapers into the environment may be either via the landfill gas or leachate. During composting, the potential emission pathways are air, final compost and perhaps leachate. The objectives of this study were therefore to determine; (1) the fate of AGM under landfill (acid and methanogenic phases) and aerobic composting conditions and (2) whether the presence of AGM had any measurable adverse effects on the processes. Radiolabelled test material $\left({ }^{14} \mathrm{C}-\mathrm{AGM}\right)$ was used to determine the fate of AGM according to the potential pathways of release.

\section{Test material description}

AGM is a lightly cross-linked, high molecular weight sodium-polyacrylate polymer. It is prepared by the polymerization of acrylic acid under controlled conditions. More broadly, AGM is a member of a group of polymers sharing a general derivation from 
acrylic acid. These polymers have a number of useful properties that have led to their use in diverse applications. They can function as absorbing, thickening, emulsifying, suspending and dispersing agents. Uses of the general class of polyacrylate polymers include hardened plastic (e.g. Plexiglass ${ }^{R}$ and Lucite ${ }^{R}$ ), cosmetics, detergents, shampoos, shaving lotions, paints and pharmaceuticals. They also have industrial (e.g. oil recovery) and agricultural (e.g. moisture retention) applications.

Since there was no available analytical method capable of measuring realistic concentrations of AGM under environmental conditions, ${ }^{14} \mathrm{C}$-labelled AGM was specially synthesized for this work. The synthesis procedure was developed in conjunction with an AGM supplier, so that the ${ }^{14} \mathrm{C}$-labelled polymer would be comparable to the commercial material. The ${ }^{14} \mathrm{C}$ was located at the 2,3-position of the polymer backbone and the ${ }^{14} \mathrm{C}$-AGM had a specific activity of $5.0 \mu \mathrm{Ci}$ per $\mathrm{mg}$.

For purposes of the test, the ${ }^{14} \mathrm{C}-\mathrm{AGM}$ was placed in the core of a baby diaper. Ten by ten $\mathrm{cm}$ pieces were cut from commercial diapers, which already contained AGM in their cores. Approximately $20 \mathrm{mg}$ of ${ }^{14} \mathrm{C}$-AGM was placed in the core of each pad. The pads were then sealed with a waterproof adhesive to keep the diaper pad intact. This modelled how a real diaper enters solid waste. ${ }^{14} \mathrm{C}$-AGM has been used in similar environmental studies (Martin et al. 1987a,b, 1990). Control pads were also used in the study. These were cut from the same lot of commercial diapers as those receiving the addition of ${ }^{14} \mathrm{C}$ AGM. The same procedure was used for these pads except that the ${ }^{14} \mathrm{C}-\mathrm{AGM}$ was omitted.

\section{Test methodology description}

\subsection{Test system overview}

The potential for solid waste to release materials to leachate is often studied by means of elution tests using water (Ham et al. 1980). However, many parameters can potentially affect the release, including $\mathrm{pH}$, redox potential, buffer capacity and ionic strength. Furthermore, standard elution tests do not allow the investigation of a material's degradation in waste. In order to address this need and maximize realism, a test procedure that simulates biological processes in landfill and composting was chosen (Stegmann 1981).

The test reactors used in this study (Fig. 1) were made of polyvinyl chloride (PVC) or aluminum (volume $c .120 \mathrm{l}$ ). These were gas-tight and leachate was collected in a plastic vessel $(2.51)$ external to the reactor. Leachate was recirculated back to the top of the waste in the reactor by means of submersible pump. Samples of the leachate were collected periodically for analysis and gas production was measured by pumping it from a gas-tight, aluminum-plastic laminated collection bag. Samples of gas were also taken for analysis. The test reactors were located in rooms heated to $30^{\circ} \mathrm{C}$. Precipitation was simulated by adding appropriate amounts of water to the waste in the test reactors. The same volume of leachate was removed for analytical purposes and to maintain water balance.

The same test system was used for simulating composting. In this case, however, the test reactors were aerated from the bottom by a peristaltic pump. The air was saturated with moisture to preclude drying out of the waste.

The reactors containing diaper pads with ${ }^{14} \mathrm{C}-\mathrm{AGM}$ were constructed of aluminum. These reactors were located in a laboratory equipped to handle radioactive materials. Heating of the lysimeter contents was achieved by circulating warm water between the 


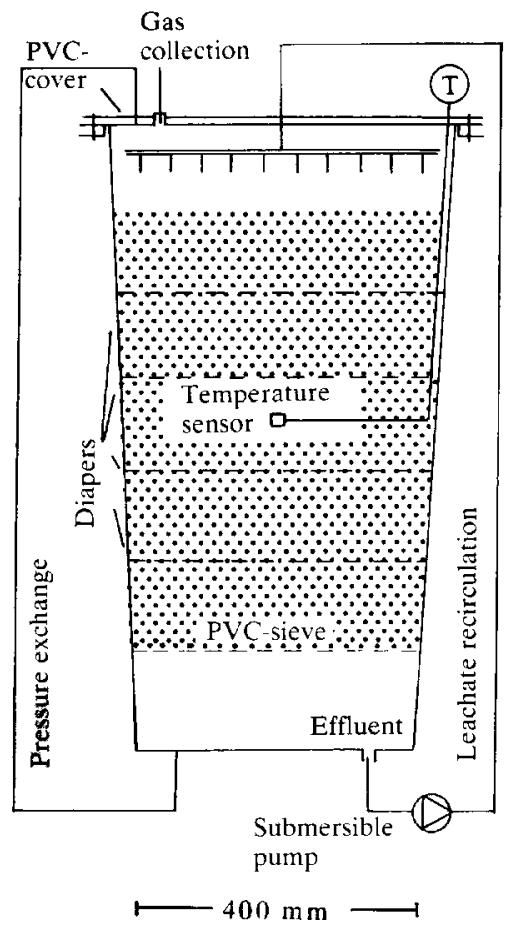

Fig. 1. Design of the test reactor (Stegmann, 1981). Base $400 \times 400 \mathrm{~mm}$.

doubled walled reactor. These reactors were equipped and operated in the same way as those constructed of PVC, which did not contain ${ }^{14} \mathrm{C}-\mathrm{AGM}$.

\subsection{Analytical measurements}

${ }^{14} \mathrm{C}$-activity was measured in the gas, leachate and solid (diaper pad, reactor contents) phases. This was done in order to develop a mass balance for the AGM. Measurement of ${ }^{14} \mathrm{C}$ was by liquid scintillation technique. Gas and solid samples were combusted in a laboratory-scale furnace (Ströhlein) to convert the ${ }^{14} \mathrm{C}$ and all organic carbon in the sample to $\mathrm{CO}_{2}$; the $\mathrm{CO}_{2}$ produced was absorbed on a standard medium (Carbosorb). For gas samples, $100 \mathrm{ml}$ aliquots were also passed through a $\mathrm{CO}_{2}$ sorbent before combustion. This allowed, by difference calculation, the determination of the amount of ${ }^{14} \mathrm{CH}_{4}$ and ${ }^{14} \mathrm{CO}_{2}$ produced. Solids were milled before combustion to provide homogenous samples. Aliquots of leachate samples $(1-2 \mathrm{ml})$ were directly injected into the scintillation counter.

Other analytical parameters, including leachate $\mathrm{pH}$, temperature, chemical oxygen demand (COD), biological oxygen demand in 5 days $\left(\mathrm{BOD}_{5}\right)$, chloride, conductivity, $\mathrm{NH}_{4}-\mathrm{N}$, TKN, sulphate, bicarbonate and volatile organic acids, were conducted according to U.S. or German standard procedures.

\subsection{Test program}

As noted previously, the fate of AGM was determined under the two predominant conditions found in a landfill: (1) acid phase and (2) methanogenic phase. Our study 
simulated these processes under optimum conditions so that the test period could be as short as possible. The following procedure were used in order to achieve this optimization:

- Utilization of shredded and homogenized MSW.

- Constant temperature of the surroundings at $30^{\circ} \mathrm{C}$.

- Water content (wet weight basis) greater than $50 \%$ for anaerobic conditions and 35$50 \%$ for aerobic conditions.

- Enhancement of the methanogenic phase by means of compost addition (MSW:compost $=2: 1$ ) (see also Stegmann 1981, Stegmann \& Spendlin 1986, 1989). The methanogenic phase can be reached after about 7 weeks with compost addition, compared to a year or longer with only shredded MSW.

Owing to safety and handling precautions, reactors containing ${ }^{14} \mathrm{C}-\mathrm{AGM}$ could not be analysed for leachate quality. For this reason, two parallel test systems were set up. One reactor (made from aluminum) contained diaper pads with ${ }^{14} \mathrm{C}$-AGM, while the other (made from PVC) contained normal diaper pads that included unlabelled AGM. Table 1 presents the experimental design and content of the test reactors. Eight reactors, labelled P1-P8, were assembled to model acid and methanoganic phases in a landfill and composting conditions. Table 2 presents an overview of the analytical parameters measured for the reactors.

Shredded MSW was used as the solid waste added to the reactors (Table 1). MSW and compost (cured for about 4 months) were added to reactors P1-P3, which simulated the methane phase. MSW only was added to reactors simulating the acid phase (P4 and P5)

TABLE 1

Experimental design of the test program and content of the test reactors (based on weight)

\begin{tabular}{|c|c|c|c|c|c|c|c|c|c|}
\hline \multirow[b]{3}{*}{ Reactor } & \multirow[b]{3}{*}{ Simulation } & \multicolumn{7}{|c|}{ Input (kg) } & \multirow[b]{3}{*}{ Label } \\
\hline & & \multicolumn{2}{|c|}{ MSW } & \multicolumn{2}{|c|}{ Compost } & \multirow{2}{*}{$\begin{array}{l}\text { Relation (by dry weight) } \\
\text { MSW: compost }\end{array}$} & \multicolumn{2}{|c|}{ Diapers } & \\
\hline & & Wet & Dry & Wet & Dry & & Wet & Dry & \\
\hline $\mathrm{P} 1$ & methane phase & 10.1 & 6.3 & 8.7 & 5.2 & $55: 45$ & 3.5 & 0.2 & ${ }^{14} \mathrm{C}$ \\
\hline $\mathrm{P} 2$ & methane phase & 10.1 & 6.3 & 8.7 & 5.2 & $55: 45$ & 3.5 & 0.2 & - \\
\hline P3 & methane phase & 10.1 & 6.3 & 8.7 & 5.2 & $55: 45$ & - & - & - \\
\hline P4 & acid phase & 17.4 & 10.9 & - & - & - & 3.5 & 0.2 & ${ }^{14} \mathrm{C}$ \\
\hline P5 & acid phase & 17.7 & 11.0 & - & - & - & 3.3 & 0.2 & - \\
\hline P6 & composting & 14.7 & 9.2 & - & - & - & 3.5 & 0.2 & ${ }^{14} \mathrm{C}$ \\
\hline P7 & composting & 20.2 & 12.6 & - & - & - & 3.5 & 0.2 & -. \\
\hline P8 & composting & 20.2 & 12.6 & - & - & - & - & - & - \\
\hline
\end{tabular}

TABLE 2

Analytical program for the test reactors

\begin{tabular}{lcc}
\hline Reactor & ${ }^{14} \mathrm{C}$-labelled AGM & \multicolumn{1}{c}{ Analytical parameters } \\
\hline P1, P4, P6 & yes & ${ }^{14} \mathrm{C}$-content of leachate, ${ }^{14} \mathrm{CO}_{2},{ }^{14} \mathrm{CH}_{4}$ in the gas, $\mathrm{pH}$ \\
P2, P3, P5 & no & $\mathrm{pH}$, conductivity, $\mathrm{BOD}_{5}, \mathrm{COD}, \mathrm{NH}_{4}^{-} \mathrm{N}, \mathrm{TKN}, \mathrm{Cl}^{-}, \mathrm{SO}_{4}^{-}$, \\
P7, P8 & & $\mathrm{HCO}_{3}^{-}$, volatile organic acids
\end{tabular}


and aerobic composting (P6-P8). The MSW and compost originated from a plant in Flensburg, Germany.

The diaper pads were placed in the waste in four layers (Fig. 1); each layer contained five pads. The pads were placed horizontally in the waste to maximize contact with leachate and were not shredded. Thus, they represent a "worst-case" situation for potential movement of AGM from the diaper. About half the pads were inside an open mesh plastic net to facilitate their collection at the end of the test.

In terms of weight, the diaper pads were $18-20 \%$ of the waste in the landfill reactors on a wet weight basis and $1.7-1.8 \%$ on a dry weight basis. For the composting simulation, the diaper pads were $16-24 \%$ of the waste on a wet weight basis and $1.6-$ $2.2 \%$ on a dry weight basis. These concentrations of diaper pads are greater than those in actual solid waste, so a degree of conservatism was built into the study.

\section{Results and discussion}

\subsection{Simulation of the methane phase of landfill}

Gas production, typical of the methane phase, started in all methane-phase reactors (P1P3) after 40 days. The gas consisted from that time until the end of the study of about $60 \% \mathrm{CH}_{4}$ and $40 \% \mathrm{CO}_{2}$. The total volume of gas formed during the study was $240-270 \mathrm{l} /$ $\mathrm{kg}$ dry matter and there was no adverse impact on gas production from including the diaper pads.

The organic content of the leachate decreased rapidly as expected, owing to conversion of organic substances into gas. There was no impact of the diaper pads on organic content $\left(\mathrm{COD}, \mathrm{BOD}_{5}\right)$ of the leachate. Within 50 days, COD in the leachate decreased from an initial value of $c .25,000 \mathrm{mg} / 1$ to $c .1500 \mathrm{mg} / 1$. Typical results are shown in Fig. 2 .

Release of ${ }^{14} \mathrm{C}$-AGM from the diaper pads to the leachate occurred during the first 60 days and then ceased (Fig. 3). Subscquent to day $100,{ }^{14} \mathrm{C}$-activity in the leachate was below detection.

The small amount of ${ }^{14} \mathrm{C}$-AGM (c. $2.4 \%$ of total ${ }^{14} \mathrm{C}$-activity) released to the leachate was likely lower molecular weight fractions. The biodegradability of this released material was also studied (see section 4.4).

A small amount (c. $0.5 \%$ of input ${ }^{14} \mathrm{C}$-activity) appeared in the gas as ${ }^{14} \mathrm{CH}_{4}$ and ${ }^{14} \mathrm{CO}_{2}$. Peak release was noted at day 60 , followed by a decrease to a nearly non-detectable level. The ${ }^{14} \mathrm{CH}_{4}$ and ${ }^{14} \mathrm{CO}_{2}$ was likely from anaerobic biodegradation of low molecular weight components in the ${ }^{14} \mathrm{C}$-AGM. Total release of ${ }^{14} \mathrm{C}$ from the $\mathrm{AGM}$ to leachate and gas during the 400 day test period was low $\left(2.9 \%\right.$ of input ${ }^{14} \mathrm{C}$ activity).

\subsection{Simulation of the acid phase of landfill}

Hydrolysis products and organic acids are the primary materials formed during the acid phase in a landfill. These compounds enter the leachate and result in high COD and $\mathrm{BOD}_{5}$ values. Gas production during the acid-phase (reactors P4 and P5) was low, about $20 \mathrm{l} / \mathrm{kg}$ dry matter, as expected. The $\mathrm{CH}_{4}$ concentration in the gas at the end of the study fell to $10 \%$, while most of the gas $(90 \%)$ was $\mathrm{CO}_{2}$ (Fig. 4 ).

The leachate COD decreased from a high of $23,000 \mathrm{mg} / 1$ to $10,000 \mathrm{mg} / \mathrm{l} \mathrm{after} 350$ days. COD results had a profile over time similar to that of chloride (Fig. 5). Consequently, reduction in the concentration of leachate COD with time was caused primarily by leaching and dilution, and not biodegradation as in the methane-phase reactors. 

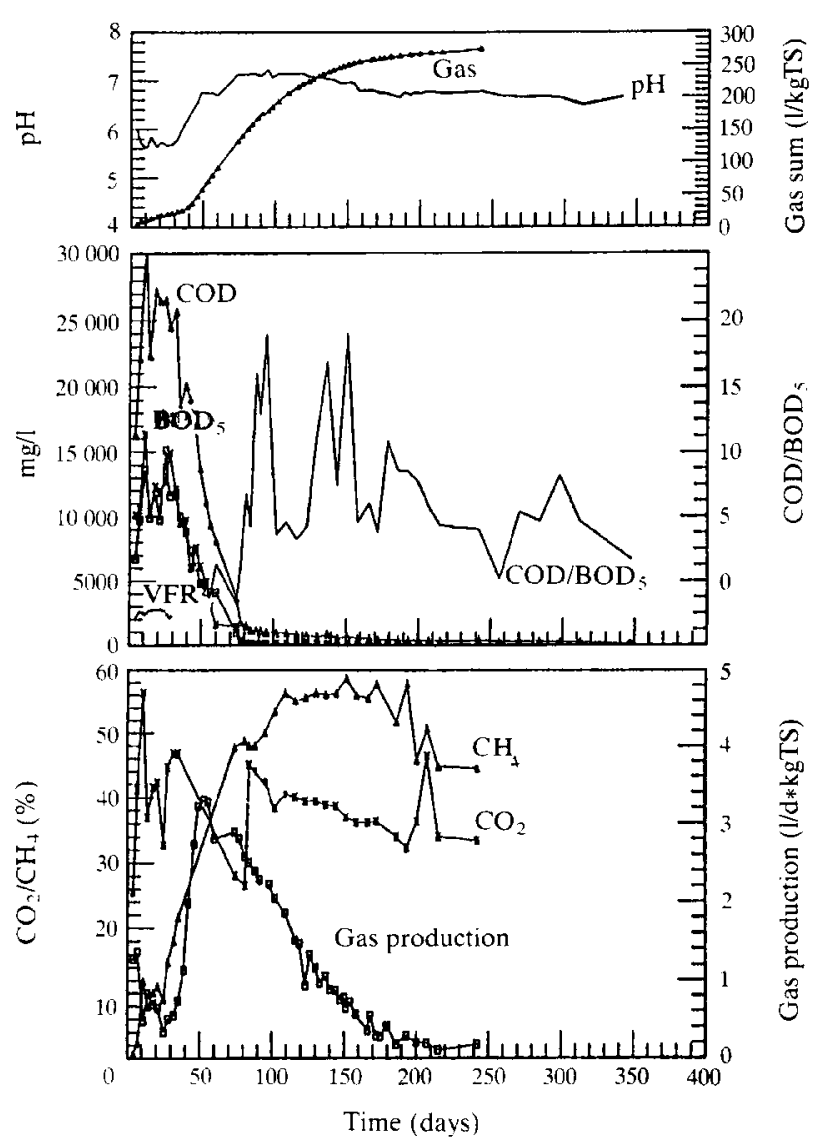

Fig. 2. Test reactor $\mathrm{P} 3$ (simulation of the methane phase); $\mathrm{pH}$, gas production, $\mathrm{COD}, \mathrm{BOD}_{5}$, organic acids, $\mathrm{CH}_{4}$ and $\mathrm{CO}_{2}$.

${ }^{14} \mathrm{C}$-activity in the leachate from reactor $\mathrm{P} 4$ decreased continuously during the 440 day test period (Fig. 6). Its profile was similar to that for COD and chloride (Fig. 5). This was likely due to leaching of lower molecular weight components from the ${ }^{14} \mathrm{C}-\mathrm{AGM}$. In total, about $4 \%$ of ${ }^{14} \mathrm{C}$-activity added via the ${ }^{14} \mathrm{C}$-AGM appeared in the leachate. The extrapolation of the calculated regression curves indicates that total emissions will be around $4.3 \%$. Compared to leachatc, the activity measured in the gas is negligible. As with the methane phase conditions, the AGM-containing diaper pads had no adverse effect on gas production or leachate composition.

\subsection{Simulation of composting}

Composting is typically conducted under aerobic conditions and favourable conditions for aerobic biodegradation are provided to stabilize the waste. In this study, water addition was practiced to provide moisture to the waste and leachate production was observed. Due to the relatively high water circulation, small anoxic pockets in the 

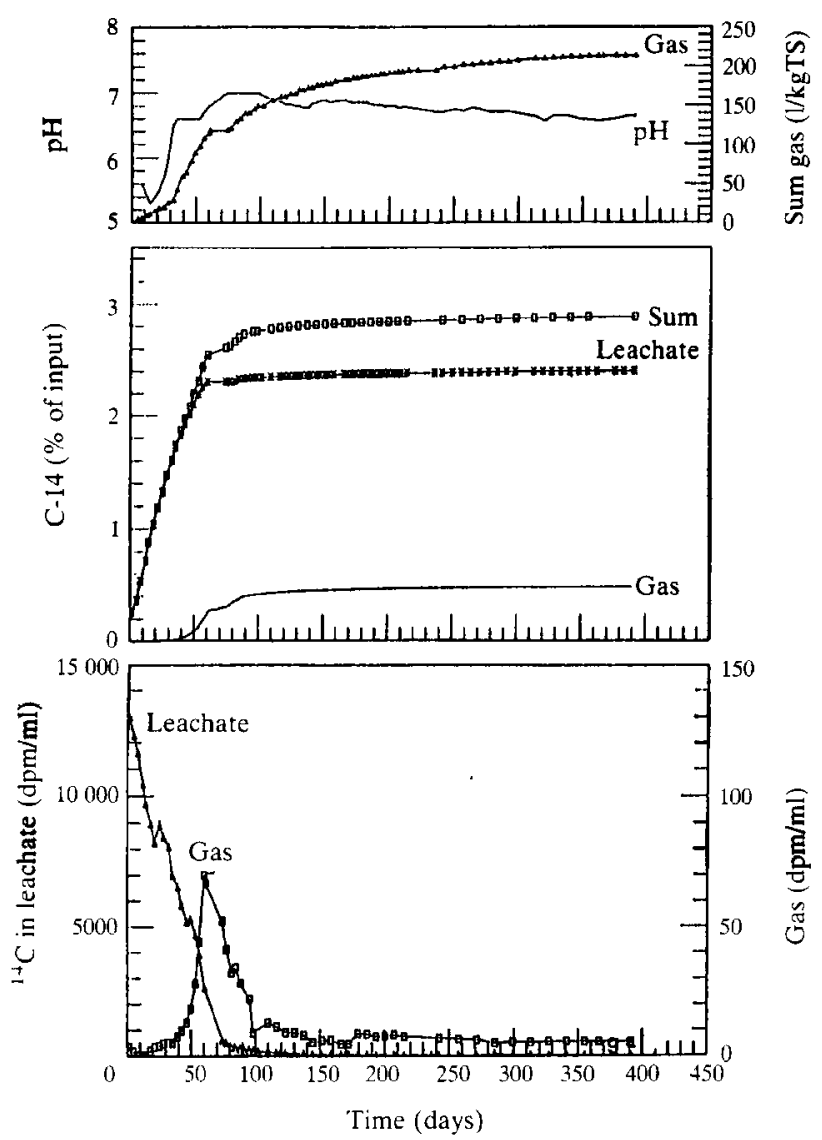

Fig. 3. Test reactor $\mathrm{Pl}$ (simulation of the methane phase); $\mathrm{pH}$, gas production, cumulative ${ }^{14} \mathrm{C}$ concentrations in the exhaust gas and leachate. $\mathrm{dpm}=$ decays per minute.

compost reactors (P6-P8) cannot be ruled out. However, significant methane concentrations (greater than 1\%) were not found in the exhaust gas, and it is concluded, accordingly, that aerobic conditions predominated.

The $\mathrm{CO}_{2}$ concentration in the gas reached a maximum of $11 \%$ at day 20 and then decreased exponentially with time and remained constant at $0.5 \%$ after 100 days. The balance was $\mathrm{N}_{2}$ and $\mathrm{O}_{2}$. The COD and $\mathrm{BOD}_{5}$ concentrations in the leachate stabilized after about 60 days at approximately $1000 \mathrm{mg} / \mathrm{l} \mathrm{COD}$ and less than $20 \mathrm{mg} / 1 \mathrm{BOD}_{5}$.

${ }^{14} \mathrm{C}$-activity from the ${ }^{14} \mathrm{C}$-labelled $\mathrm{AGM}$ was emitted essentially via the gas as ${ }^{14} \mathrm{CO}_{2}$ (Fig. 7). At the end of the study (510 days), ${ }^{14} \mathrm{CO}_{2}$ emission was $5.9 \%$ of the total ${ }^{14} \mathrm{C}$ activity added and this emission was still occuring. The release of ${ }^{14} \mathrm{CO}_{2}$ was likely due to on-going biodegradation of low molecular weight fractions in the ${ }^{14} \mathrm{C}-\mathrm{AGM}$.

Release of ${ }^{14} \mathrm{C}$-activity to the leachate was low, in total about $0.6 \%$ (Fig. 7) due to the low leachate production rate. A theoretical annual emission was calculated from the ${ }^{14} \mathrm{CO}_{2}$ in the gas and found to be $1.2 \%$. As lower molecular weight fractions are biodegraded, however, this emission may decrease as only high molecular weight polymer components would remain. As observed in the reactors simulating landfill, the 

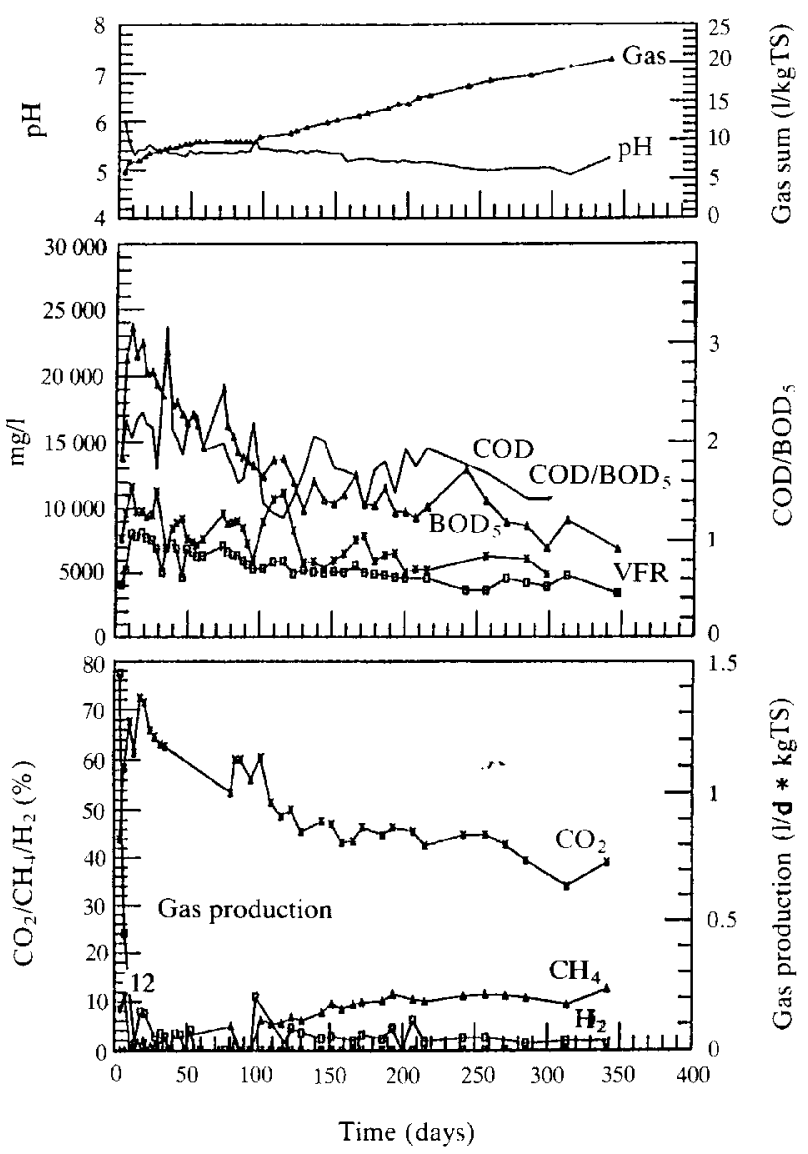

Fig. 4. Test reactor $\mathrm{P} 5$ (simulation of the acid phase); $\mathrm{pH}$, gas production, $\mathrm{COD}, \mathrm{BOD}_{5}$, organic acids, $\mathrm{CH}_{4}$, $\mathrm{CO}_{2}$ and $\mathrm{H}_{2}$.

AGM-containing diaper pads caused no adverse effect on gas production or leachate composition.

\subsection{Biodegradation of ${ }^{14} \mathrm{C}$-materials in landfill leachate}

The results from the simulation of the methane and acid phases of a landfill indicated that $2-4 \%$ of the ${ }^{14} \mathrm{C}$-activity from the ${ }^{14} \mathrm{C}$-AGM appeared in leachate (reactors $\mathrm{P} 1$ and P4). Leachate is normally treated aerobically at modern landfills before discharge and consequently the biodegradability of the ${ }^{14} \mathrm{C}$-material from the $\mathrm{AGM}$ in these leachates was studied.

Collected leachate was placed in sealed bottles and then aerated. Carbon dioxide in the exhaust air was trapped and a check was made to assure sufficient nutrients. A mass balance on ${ }^{14} \mathrm{C}$-activity was performed by analysing the exhaust air for ${ }^{14} \mathrm{CO}_{2}$ and ${ }^{14} \mathrm{C}$ in the suspended (biomass) and dissolved (filtration techniques) fractions of the leachate.

Test duration was 266 days with the leachate from reactor P1 and 102 days with leachate from reactors $\mathrm{P} 4$ and $\mathrm{P} 5$. 


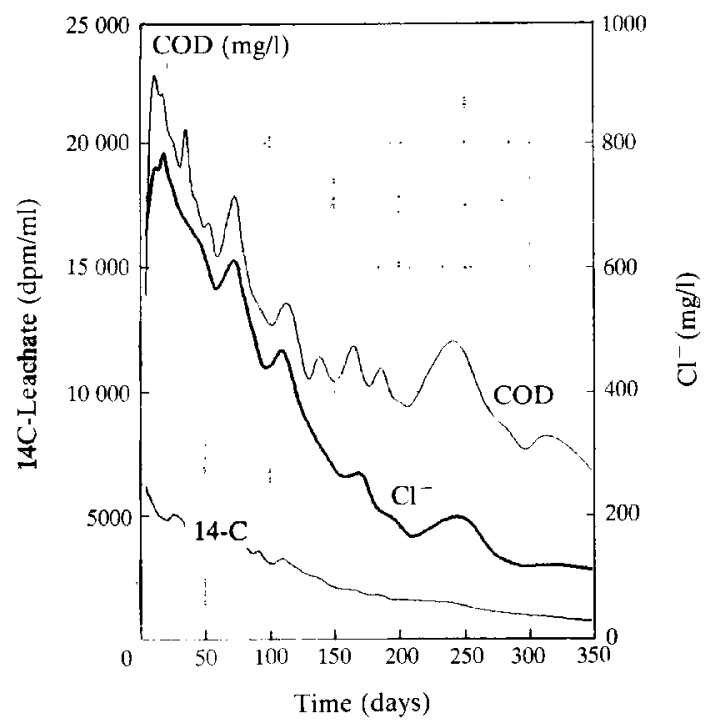

Fig. 5. Test reactors P4-P5 (simulation of the acid phase): comparison of $\mathrm{Cl}(\mathrm{P} 5)$, COD (P5) and ${ }^{14} \mathrm{C}(\mathrm{P} 4)$ concentrations.

Leachate from reactor Pl (methane phase) for this biodegradation test was collected during the first 53 days of the landfill simulation, while leachate from reactors $\mathrm{P} 4$ and P5 (acid phase) was older, being collected between days 285-327 for P4 and 313-320 for P5. ${ }^{14} \mathrm{C}$-labelled carboxylic acids (acetic, propionic, butyric) were added to the collected leachate from reactor $\mathrm{P} 5$ for reference purposes $\left({ }^{14} \mathrm{C}\right.$-AGM was not present in reactor P5). By comparing the ${ }^{14} \mathrm{C}$-degradation kinetics it could be determined whether the ${ }^{14} \mathrm{C}$ activity remained primarily in the organic acids. Furthermore, sludge from a municipal wastewater treatment plant was added to separate bottles containing leachate from reactors $\mathrm{P} 1$ and $\mathrm{P} 4$ to provide an inoculum of sewage organisms (B2 and $\mathrm{B} 4$ in Fig. 8).

Results are summarized in Fig. 8. There was no indication that addition of sewage sludge to leachate from reactors PI and P4 gave substantially different end-results from the parallel biodegradation test where sludge was not added.

Accordingly, there was sufficient microbial activity coming from the leachate itself. This is also confirmed by the results from the ${ }^{14} \mathrm{C}$-labelled carboxylic acids added to leachate from reactor P5 (B5 in Fig. 8). The added ${ }^{14} \mathrm{C}$-labelled organic acids were degraded much faster and more completely than the ${ }^{14} \mathrm{C}$-compounds in leachate of the reactors $\mathrm{P} 1$ and $\mathrm{P} 4$. From these findings it can be concluded that the activity in the leachate is not only in the organic acids.

${ }^{14} \mathrm{CO}_{2}$ evolution from the ${ }^{14} \mathrm{C}$-activity in the leachates from reactors $\mathrm{P} 1$ and $\mathrm{P} 4(\mathrm{~B} 1-\mathrm{B} 4$ in Fig. 8) was $55-72 \%$ of the theoretical. About $5-10 \%$ of the ${ }^{14} \mathrm{C}$-activity was associated with the biomass and $2-5 \%$ as dissolved material in the aqueous phase, $1-5 \%$ could be detected in the dissolved $\mathrm{CO}_{2}$. Overall mass balances were $70-95 \%$, based on the ${ }^{14} \mathrm{C}$ activity present at the start of the biodegradation test. Kinetics of mineralization were, however, different among the biodegradation test vessels; $95 \%$ of the total ${ }^{14} \mathrm{CO}_{2}$ evolved was reached in 68-73 days for vessels B1-B4 (Fig. 8) and 47 days for vessel B5.

These results indicate that the ${ }^{14} \mathrm{C}$-material leached from the ${ }^{14} \mathrm{C}$-AGM in both the methane and acid-phase landfill reactors was highly biodegradable. The leached 


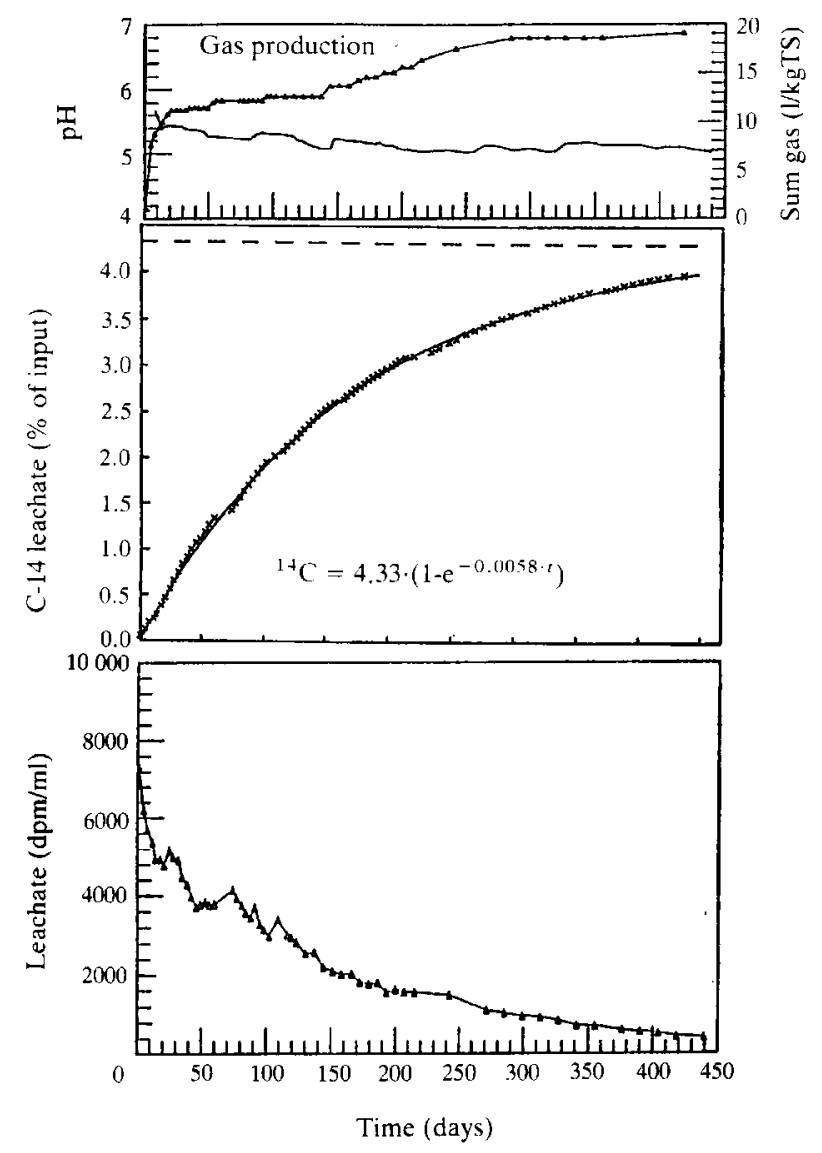

Fig. 6. Test reactor $\mathrm{P} 4$ (simulation of the acid phase); $\mathrm{pH}$, gas production, cumulative ${ }^{14} \mathrm{C}$ concentrations in the leachate (cumulative ${ }^{14} \mathrm{C}$-release in the gas phase was approximately zero).

materials were probably lower molecular weight components from the AGM, which should be more readily biodegradable than higher molecular weight ones.

\subsection{Mass balance calculation for $A G M$ fate}

Determination of AGM required not only the analysis of gas and leachate from the reactors for ${ }^{14} \mathrm{C}$, but also the diaper pads and waste in the reactors at the end of the test. This was a complex undertaking owing to the non-homogeneous nature of the materials.

For the solid waste in the reactors, three samples from each of five layers were taken, dried, milled and homogenized, and then combusted with subsequent analysis of ${ }^{14} \mathrm{C}$ (as ${ }^{14} \mathrm{CO}_{2}$ ). Table 3 presents the results.

Eleven percent of the initial ${ }^{14} \mathrm{C}$-activity from the ${ }^{14} \mathrm{C}$-AGM was present in the solid waste of the methane or acid phase reactors (Pl and P4). A greater amount was present in the solid waste of the compost reactor (P6), $42 \%$ of the inital ${ }^{14} \mathrm{C}$-activity.

Diaper pads removed at the end of the test were dried, cut into small pieces, milled and mixed. Seven samples each from two different diaper groups were then combusted with analysis for ${ }^{14} \mathrm{CO}_{2}$. The results in Table 3 indicate that about $50 \%$ of the ${ }^{14} \mathrm{C}$-activity from 

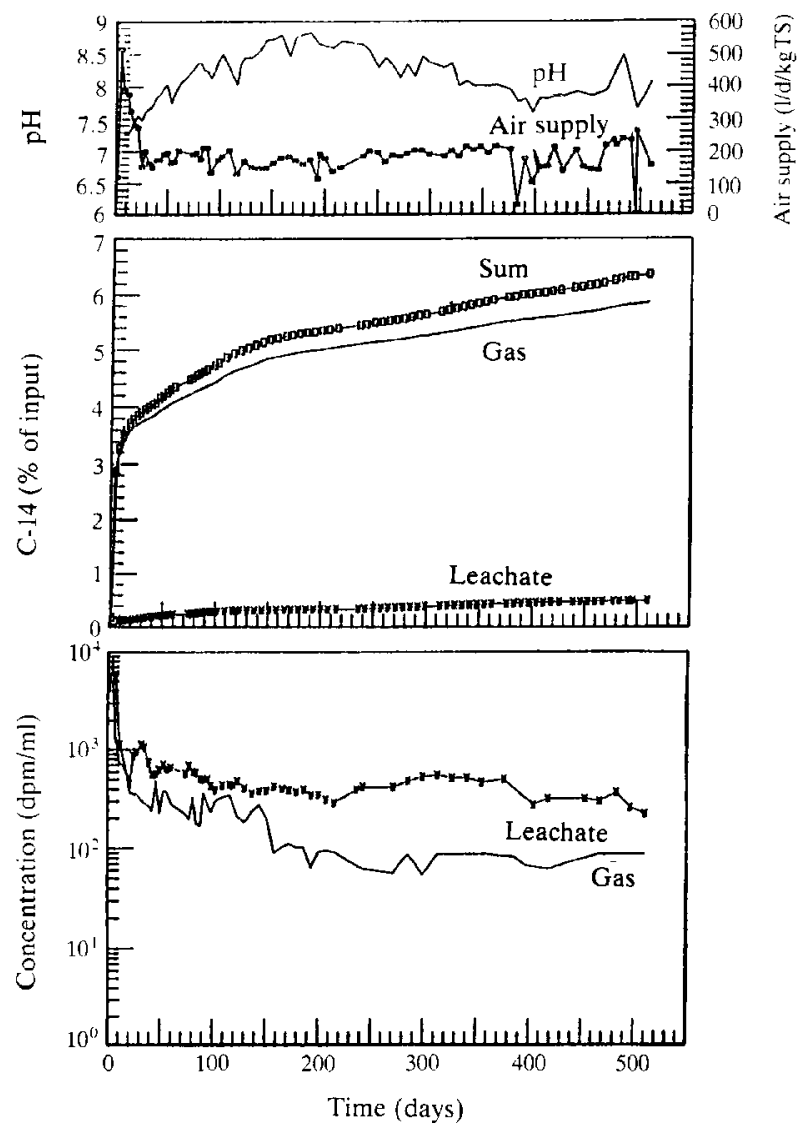

Fig. 7. Test reactor $\mathrm{P} 6$ (simulation of composting); $\mathrm{pH}$, air supply cumulative ${ }^{14} \mathrm{C}$ emission and ${ }^{14} \mathrm{C}$ concentration in the exhaust gas and leachate.

the ${ }^{14} \mathrm{C}$-AGM was still present in the diaper pads for the reactors simulating landfill (P1 and P4) and about 30\% for the composting simulation (P6). Evaluating the composting test results it has to be noted that the first set of test pads, where lower ${ }^{14} \mathrm{C}$ concentrations were detected, had been placed in the lowest level of the test container.

TABLE 3

${ }^{14} \mathrm{C}$-activity in the solid waste and diaper pads at test end as a percentage of the initial activity

\begin{tabular}{|c|c|c|c|}
\hline & \multicolumn{3}{|c|}{ Simulation of } \\
\hline & $\begin{array}{l}\text { Methane phase } \\
\text { (Reactor P1) }\end{array}$ & $\begin{array}{l}\text { Acid phase } \\
\text { (Reactor P4) }\end{array}$ & $\begin{array}{l}\text { Composting } \\
\text { (Reactor P6) }\end{array}$ \\
\hline $\begin{array}{l}\% \text { of }{ }^{14} \mathrm{C} \text { from } \mathrm{AGM} \text { in solid waste } \\
\% \text { of }{ }^{14} \mathrm{C} \text { in } \mathrm{AGM} \text { in the diaper pads }\end{array}$ & 11 & 11 & 42 \\
\hline Diaper pad group 1 & 60.3 & 54.6 & 20.5 \\
\hline Diaper pad group 2 & 45.2 & 50.1 & 40.9 \\
\hline Standard deviation & 20,25 & 23,12 & 4,4 \\
\hline
\end{tabular}




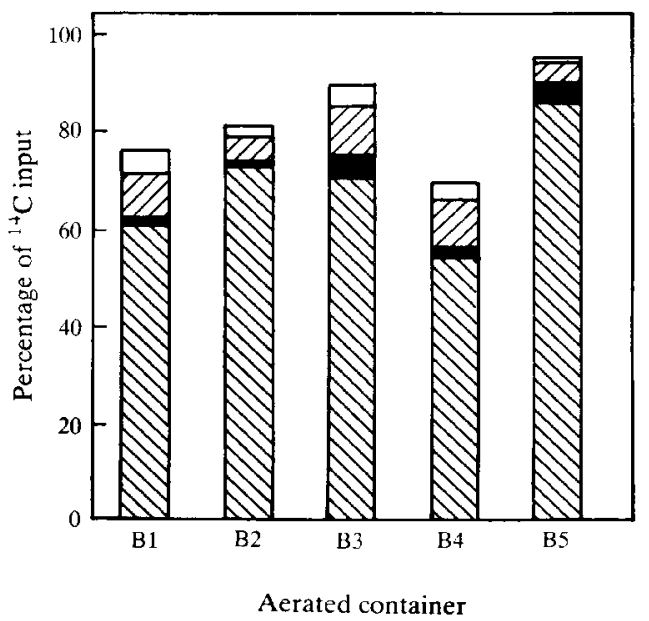

Fig. $8 .{ }^{14} \mathrm{C}$ balance of the leachate biodegradation tests, see text. (\$) ${ }^{14} \mathrm{CO}_{2}$ output; $(\boldsymbol{\square})$ dissolved ${ }^{14-} \mathrm{CO}_{2} ;(\mathbb{Q})$ dry matter; $(\sqcup)$ filtrate.

Due to the artificial aeration through the bottom of the test container, oxygen supply was higher in this area.

Overall mass balance for ${ }^{14} \mathrm{C}$-activity, summing that present in gas, leachate, solid waste and diaper pads, was $60-75 \%$ for the landfill simulations and $70-90 \%$ for the composting simulation (Fig. 9). This is judged acceptable, given the complex nature of the sampling, sample preparation and analysis procedures that were required.

The diaper pads retrieved from the reactors simulating the methane phase of landfill (P1) and composting (P6) were very deteriorated visually and consisted essentially of only the outer plastic films. The cellulose in the pad core appeared to be largely degraded and particles of AGM were not visible. In contrast, the diaper pads retrieved from the acid-phase reactor $(\mathrm{P} 4)$ appeared well preserved visually. Extensive degradation of the cellulose was not apparent. This is not surprising, owing to low biological activity under acid phase conditions.

The mass balance information was used to calculate the overall fate of AGM during landfill and composting (Fig. 10). For landfill, over 75\% of the AGM is predicted to stay within the diaper, about $16 \%$ to enter the surrounding solid waste, $6 \%$ to enter leachate and $0.5 \%$ to biodegrade and enter landfill gas as $\mathrm{CO}_{2}$ and $\mathrm{CH}_{4}$. Furthermore, the fraction entering leachate is biodegradable under the aerobic conditions employed to treat leachate before discharge. Long-term effects on the biodegradation of the high molecular weight components of the AGM are difficult to predict.

Based on the composting conditions of this test (diaper pad placed in the solid waste but not shredded or mixed into the waste), $40 \%$ of the AGM is predicted to remain in the diaper, $52 \%$ to enter the solid waste/compost, $7.5 \%$ to biodegrade and enter the air as $\mathrm{CO}_{2}$ and $0.5 \%$ to enter leachate (if leachate is generated). In an actual composting operation, where the diaper disassembles and is intimately mixed in to the waste, the diaper core (pulp plus AGM) enters the compost and the plastic components are screened out (Hopping, 1991). Thus, one expects that most of the AGM will enter the compost and that a relatively small fraction, in the range of $5-10 \%$, will biodegrade. 


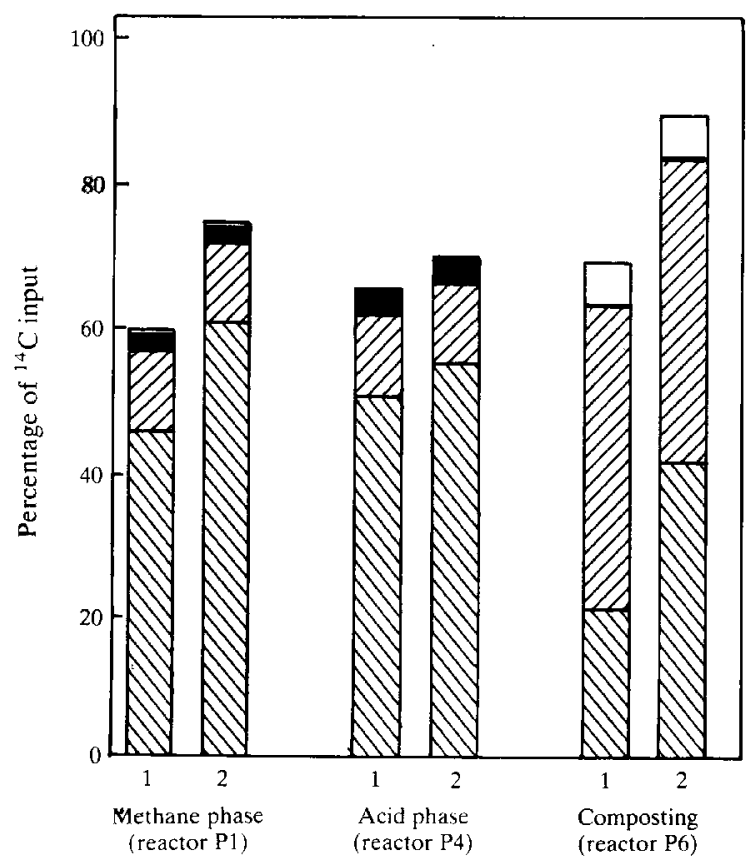

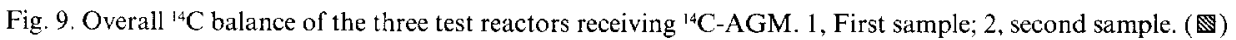

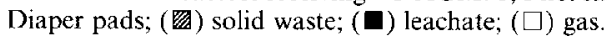

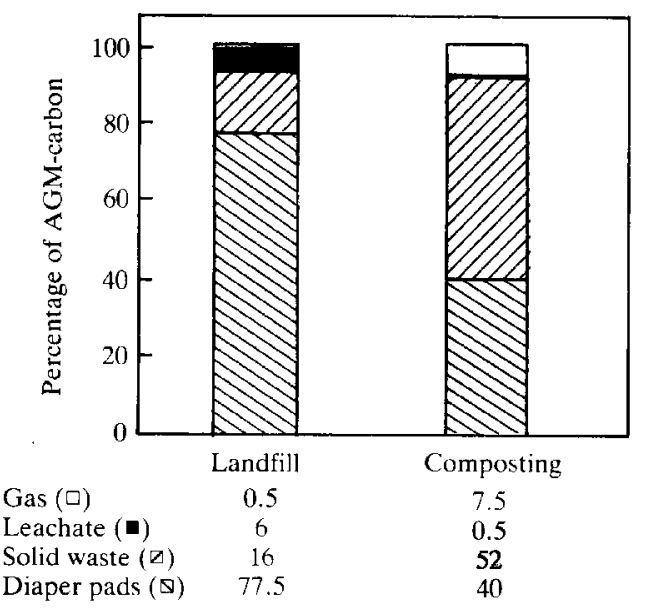

Fig. 10. Predicted fate of AGM during landfill and composting of panty diapers, normalized to $100 \%{ }^{14} \mathrm{C}$ mass recovery in the test reactors (actual recoveries were 60-90\%). 
Biodegradation may continue on a long-term basis, because measureable production of ${ }^{14} \mathrm{CO}_{2}$ was still occuring at test end although decay of microbial biomass formed earlier is another possible source of ${ }^{14} \mathrm{CO}_{2}$.

\section{Summary and conclusions}

A cross-linked, sodium-polyacrylate polymer (referred to as AGM) has been developed for use in panty diapers. This study evaluated the fate and effects of AGM under landfill and composting conditions. ${ }^{14} \mathrm{C}-\mathrm{AGM}$ coupled with radiotracer techniques were employed to determine AGM fate and to construct mass balances.

In order to reduce time requirements, the tests were performed in 120 litre reactors filled with shredded municipal solid waste, or municipal solid waste plus compost, placed in a $30^{\circ} \mathrm{C}$ environment and operated with leachate recycle. Specially prepared diaper pads containing $20 \mathrm{mg}$ of ${ }^{14} \mathrm{C}$-AGM each were placed at various levels in the solid waste and the diaper pad concentration in the waste was greater than that in actual practice. ${ }^{14} \mathrm{C}$-activity in the gas phase (as $\mathrm{CH}_{4}$ and $\mathrm{CO}_{2}$ ), leachate, waste and diaper pads was measured by liquid scintillation techniques. ${ }^{14} \mathrm{C}$-material from the ${ }^{14} \mathrm{C}$-AGM that appeared in the landfill leachate was subjected to acrobic biodegradation tests.

The following results were observed:

- Most of the AGM ( $>90 \%$ ) remained in the diaper pad and surrounding waste under conditions simulating the acid and methanogenic phases of a landfill.

- Only a small fraction of the AGM biodegraded $(0.5 \%)$ under methanogenic landfill conditions; biodegradation under acid landfill conditions was essentially nil.

- A few percent of the AGM (2-4\%) appeared in the leachate. This material biodegraded under aerobic conditions.

- There was no indication that AGM had any adverse effect on gas production or leachates composition under methanogenic conditions.

- Under conditions simulating aerobic composting, most $(>90 \%)$ of the AGM was associated with the diaper pad and waste, while $5.9 \%$ biodegraded (i.e. appeared in the gas phase as $\mathrm{CO}_{2}$ ) and $0.6 \%$ was present in the leachate. Furthermore, biodegradation, as evidenced by ongoing $\mathrm{CO}_{2}$ production, was still continuing at study end. There was no adverse effect by the AGM on the composting as indicated by leachate parameters and gas production.

On the basis of this investigation, it is concluded that during landfilling of diapers containing AGM, over $90 \%$ of the AGM remains in the diaper and surrounding waste, with little biodegradation, as expected, for a polymeric material. A few percent of the AGM, probably lower molecular weight components, may appear in the leachate, but these components are biodegradable aerobically. In terms of composting under aerobic conditions, AGM will enter the compost and a larger percentage than under landfill conditions will biodegrade, although this still is a small fraction of the total AGM. Biodegradation long-term may continue and a rate of $1.2 \%$ per year was calculated.

Finally, the test system and procedures described here may have use for evaluating other materials disposed to solid waste. The fate and effects of a material or product can be studied under realistic conditions and use of a radiotracer facilitates construction of mass balances. The co-mixing of compost with solid waste, the use of a controlled temperature environment and the practice of leachate recycle allow the acceleration of landfill processes, thus usefully shortening the necessary length of a study. 


\section{References}

Carra, J. S. \& Cossu, R. (1990) International Perspectives on Municipal Solid Wastes and Sanitary Landfilling. London, U.K.: Academic Press.

Christensen, T. H. \& Kjeldsen, P. (1989) Basic biochemical processes in landfills. In Sanitary Landfilling: Process, Technology and Environment Impact (T. H. Christensen, R. Cossu \& R. Stegmann, eds). London, U.K.: Academic Press.

Ham, R. K., Anderson, M. A., Stegmann, R. \& Stanforth, R. (1980) Die Entwicklung eines Auslaugtcsts für Industrieabfälle (Development of a leaching test for industrial waste). Müll und Abfall 7.

Hopping, W. D. (1991) Composting of baby diapers-a research program. Talk at seminar on source separation of waste and composting, 7 March 1991, Gent, Belgium.

Martin, J. E. et al. (1990) Carbon-14 tracer study of polyacrylate polymer in a wastewater plant. Applied Radiation Isotopes 41(10/11), 1165-1172.

Martin, J. E., Howard, K. W. F. \& King, L. W. (1987a) Environmental behavior of ${ }^{14} \mathrm{C}$ tagged polyacrylate polymer. Column studies of flow and retardation in sand. Nuclear and Chemical Waste Management 7, 265-271.

Martin, J. E., Howard, K.W. F. \& King, L. W. (1987b) Environmental behavior of ${ }^{14} \mathrm{C}$ tagged polyacrylate polymcr. Flow tank studies of flow and retention in sand. Nuclear and Chemical Waste Management 7, 273-280.

Schobert, S. (1978) Mikrobielle Methanisierung von Klärschlamm (Microbic methane formation from sewage sludge). Expertengespräch am 20.6.89, Projektträgerschaft Biotechnologie, Kernforschungsanlage Jülich (Expert talk on 06.20.89, Project Institution Biotechnology, Nuclear Research Plant Jülich, Germany). Proceedings.

Stegmann, R. (1981) Beschreibung eines Verfahrens zur Untersuchung anaerober Umsetzungsprozesse von festen Abfallstoffen im Labormaßstab (Description of a procedure to investigate anaerobic degradation processes of solid waste in laboratory scale). Müll und Abfall 2.

Stegmann, R. \& Spendlin, H.H. (1986) Research activities on enhancement of biochemical processes in sanitary landfills. Water Pollution Research Journal Canada 21(4).

Stegman, R. \& Spendlin, H. H. (1989) Enhancement of degradation: German experiences. In Sanitary Landflling: Process, Technology and Environmental Impact. (T. H. Christensen, R. Cossu, \& R. Stegmann, eds). London, U.K.: Academic Press. 